\title{
Teacher Leadership and Conflict Management in EFL Classroom in the Light of the Contingency Theory of Human Resource Management: An Interdisciplinary Study
}

\author{
Elham Yazdanmehr* \\ Attar Institute of Higher Education, Mashhad, Iran \\ Yousef Ramezani \\ Attar Institute of Higher Education, Mashhad, Iran \\ Fatemeh Aghdassi \\ Imam Reza University, Mashhad, Khorasan Razavi, Iran
}

\begin{abstract}
The present interdisciplinary research was enlightened by the contingency theory of human resource management (HRM) and aimed to explore Iranian EFL teachers' leadership and conflict management styles in the private sector. To this aim, Fiedler's leadership measurement instrument along with Thomas \& Kilmann's conflict management instrument were used to collect data from 51 EFL teachers teaching in private language institutes of Khorasan Razavi, Iran. The aim was to find what proportion of teachers were task-oriented and what proportion were relation-oriented in leadership, and which conflict management styles were more prevalent among task-oriented and which were dominant among relationoriented teachers. Furthermore, comparisons were made between male/female, younger (20-30 yrs.)/older (>30 yrs.) and experienced ( $>5 \mathrm{yrs}$.)/novice $(<5 \mathrm{yrs}$.) teachers in terms of the leadership style as well as the conflict management style. Descriptive as well as inferential statistics were used to analyze the data in SPSS21. The results revealed that the majority of participants used task-oriented leadership style in class. Task-oriented teachers showed to use the accommodating conflict management style more while relation-oriented teachers prevalently used the collaborating style. Statistically significant differences were found between demographic groups in terms of the leadership and conflict management styles. Awareness of different leadership and conflict management styles can enrich teacher training courses and professional development programs in Applied Linguistics.
\end{abstract}

Index Terms - conflict management style, contingency theory, EFL teacher, leadership style

\section{INTRODUCTION}

Leadership was first studied in a variety of contexts including the military, and the contingency theory in management to which leadership concept belongs was primarily based on research findings in such domains but it is currently applied in other domains including education (Virkus, 2009). According to the contingency theory, a leader's style works best when it fits with the group environment but is still adequately flexible to adapt to a wide range of changing circumstances. This model initially provided much of the groundwork for further research on situational management theory (Northouse, 2007).

Fiedler, the pioneer of the contingency theory, measured leadership style with the Least Preferred Co-Worker Scale (LPC scale.) The leaders scoring high on this scale were perceived as relationship motivated and those scoring low were considered task motivated. Central to the contingency theory is the concept of situation-specificity. A high score on the leadership style instrument exhibits a positive orientation towards human relations. It shows that the respondent gets along with people. The nature of the task is less important and issues in doing it may be compensated for with good human relations. When the environment is such that each group member is independent, such as in a scientific setting, tasks may not be all that well defined, and a leader must rely more on his/her personality to accomplish goals (Fiedler, 1958).

Central to the contingency theory is the concept of situation-specificity (Fiedler, 1958). The situation-specific nature of EFL/ESL teaching is also significant (Huang, Yang \& Hwang, 2010). Yet, contingency theory has not yet been applied to the English Language Teaching (ELT) domain, to which teacher leadership and class management is a core

\footnotetext{
${ }^{*}$ Corresponding author
} 
concept (Yazdanmehr, Akbari, Kiany, Ghaffarsamar, 2016). Another aspect of management, and here more specifically in class management, is conflict management. Thomas and Kilman (1974) defined conflict management along two independent dimensions: assertiveness and cooperativeness. The former is the degree to which you try to satisfy your own concerns, and the latter is the degree to which you try to satisfy the other person's concern. The result is five distinct styles: avoiding, competing, collaborating, accommodating and compromising. This pattern is explored in the present research in the sample of teachers.

\section{Purpose of Research}

Contingency theory and its central features such as situation-specificity, leadership and task accomplishment along with conflict management have not yet been applied in concert to the English Language Teaching (ELT) domain, which is ripe for the discussion of teacher leadership and class management. Moreover, the body of existing literature, as will be presented in the second section, lacks any interdisciplinary research with this concern though we are aware that interdisciplinary investigations can make great and rich contributions to at least two academic fields of study, and have the benefit of a wider, more comprehensive outlook with fewer biases leaning toward one particular domain. Thus, the present research aimed to fill this gap and address EFL teacher leadership and conflict management in class in the light of a popular theory taken from the field of human resource management now applied to the ELT domain. Thus, the following research questions were addressed:

RQ1: What proportion of Iranian EFL teachers in the private sector are task-oriented and what proportion are relation-oriented in leadership style?

RQ2: Which conflict management styles are more prevalent among task-oriented and which are more prevalent among relation-oriented Iranian EFL teachers?

RQ3: Is there any statistically significant difference between demographic categories of Iranian EFL teachers in terms of leadership style and conflict management styles?

RQ3.1. Is there any statistically significantly difference between male and female EFL teachers in terms of leadership and conflict management styles?

RQ3.2. Is there any statistically significant difference between younger (20-30 yrs.) and older (>30 yrs.) EFL teachers in terms of leadership and conflict management styles?

RQ3.3. Is there any statistically significant difference between experienced EFL teachers $(>5 \mathrm{yrs}$.) and novices $(<5$ yrs.) in terms of leadership and conflict management styles?

For RQ3, the following null hypothesis was proposed:

HO: There is no statistically significant difference between demographic categories of Iranian EFL teachers in terms of leadership and conflict management styles.

\section{REVIEW OF THE RELATED LITERATURE}

\section{A. Teacher Leadership}

Emira (2010) evaluated, firstly, the definition of leadership in the eyes of Egyptian teachers and formal leaders. Secondly, he searched out their views on the association of teacher leadership and decision-making. The research was done on a group of 20 Egyptian teachers. The results showed that teachers defined teacher leadership in terms of the characteristics of leaders, styles of leadership and what teachers do both inside and outside classroom.

Mujis, Chapman and Armstrong (2013) explored whether early-career teachers could be teacher leaders or not. In this research, surveys and interviewed were conducted with Teach-First (TF) teachers, heads, middle managers and non-TF teachers. The results showed that Teach-First teachers were eager and capable for exercising leadership; however, school support, senior management commitment to distributed leadership and practical hands-on support was needed at the departmental level.

In November 2006, Muijs and Harris focused on how teacher leadership can affect school and teacher improvement; besides, the in-school factors, which can be facilitative or obstructive in the development of teacher leadership, were explored. The results indicated that a variety of formal and informal groupings contributed to teacher leadership. It also drew attention to the impact of teacher leadership, teacher empowerment and school improvement.

Aliakbari and Sadeghi (2014) examined teacher leadership practice among Iranian school teachers. The main purpose of the research was to evaluate teachers' perceptions of teacher leadership practice in schools and to examine whether these perceptions could be influenced by such variables as gender, age, teachers' educational degree, teaching experience and school level or not. Teacher leadership showed to be practiced often in the selected schools. However, teachers' age, gender, and years of teaching experience were not reflected as meaningful factors in this research, but significant differences were found in teachers' perceptions of teacher leadership practice considering their educational degree and the level they taught.

Azar and Asiabar (2014) studied self-concerned leadership styles of healthcare administrators of Iran University of Medical Sciences and also explored the relationship between self-concerned leadership effectiveness and self-concerned leadership readiness. The results showed that the highest rate belonged to transformational leadership style among Iran University of Medical Sciences healthcare executives. Khany and Amoli (2013), in their research, delved into the relationship between leadership style, job satisfaction, teacher retention and their respective sub-scales. The researchers applied Osborne and Reiman's (2005) Teacher Perception of Success and Teacher Retention Questionnaire, Fiedler \& 
Garcia's (1987) Leadership Questionnaire, Sternberg's Thinking Style Questionnaire (1991), and Smith's Job Satisfaction Questionnaire (1969) to collect the required data. The results revealed that there was almost a strong correlation between job satisfaction and teacher retention and between leadership style and teacher retention.

Koosha, Liaghat and Sadeghdaghighi (2015) aimed to explore a sample of EFL Iranian teachers' perceptions of the practice of teacher leadership through some quantitative research. For this purpose, a questionnaire adopted from a Questionnaire of Teacher Leadership School Survey developed by Katzenmeyer and Moller (2009) was disseminated among 60 EFL teachers of four institutes in Alborz province in Iran. The results indicated that most EFL teachers, though in differing degrees, practiced and applied a level of teacher leadership in their classes.

\section{B. Conflict Management}

Conflict has been studied over centuries by many scholars. However, more systematic studies were made possible not later than the twentieth century (Schellenberg, 1996). Bohannan (1967) characterizes conflict to be as basic as culture is in society, which is possibly controlled and utilized profitably for better cultural development and maintenance of social order. Schellenberg (1996) states that conflict is neither bad nor good, but one of the essentials in human social life. Gluckman (1956), Gulliver (1963) and Nanda (1994) agree on the view that conflict is a part of social life and society cannot exist without it.

In 1974, Thomas and Kilmann developed and introduced their Conflict Mode Instrument (TKI), which assessed an individual's behavior in conflicting situations: those in which the concerns of two people appeared to be incompatible. Afzal (2004) investigated the moderating or mediating effects of conflict management strategies on the relationship between conflict and job performance and concluded that employees should also be encouraged to minimize their bargaining strategy to improve their job performance. This would require conflict management training of the employees. Managers need to be trained to encourage their subordinates to use more integrating and less avoiding styles of handling conflict to improve job performance. Susan and Patti (2007) found that the prevalent style for nursing students was compromise, followed by avoidance. In contrast, avoidance, followed by compromise and accommodation was the prevalent style for allied health students.

To complement the above-mentioned related literature, the present research was carried out in the Iranian context. It further enjoys the novelty of exploring conflict management together with leadership style. This work of research is also innovative as it is pioneering to investigate the target variables in the Iranian context in the light of the contingency theory.

\section{METHODOLOGY}

\section{A. Participants and Setting}

Fifty-one Iranian EFL teachers affiliated with the private sector participated in this research. Their demographic information is presented in Table 1.

TABLE 1

PARTICIPANTS’ DEMOGRAPHIC INFORMATION

\begin{tabular}{llllllll}
\hline variable & gender & \multicolumn{3}{c}{ age } & \multicolumn{2}{l}{ Years of experience } \\
\hline Sub-variable & male & female & $<20$ & $20-30$ & $>30$ & $<5$ & $\geq 5$ \\
\hline n. & 14 & $37(72.5 \%)$ & 0 & 21 & 30 & 24 & 27 \\
& $(27.5 \%$ & & & $(41.2 \%)$ & $(58.8 \%)$ & $(47.1 \%$ & $(52.9 \%)$ \\
& ) & & & & & \\
\hline total & $51(100 \%)$ & $51(100 \%)$ & & & $51(100 \%)$ \\
\hline
\end{tabular}

The data were collected in summer, 2019. The private language institutes the subjects were affiliated with were among those with the best and longest reputation of teaching English as a foreign language in Khorasan Razavi. Moreover, some had multiple branches in different parts of Iran and a central teaching system homogeneously applied to these branches. The reason why these institutes were selected was to obtain more generalizable results.

\section{B. Instrumentation}

Two questionnaires were used in the present research, one for teacher leadership style and the other for conflict management style. The former was the LPC scale, originally developed to measure a manager's leadership style (either task-oriented or relation-oriented). Here in the present research, an adapted version of this scale (LPS) was used to fit teacher leadership style in class management and dealing with students. A respondent (here, an EFL teacher) would choose between 18 and 25 sets of adjectives on an 8-point scale between each of values to rate a student with whom s/he would least want to work (in class). For the latter, Thomas and Kilmann's TKI questionnaire was used. It included a repertoire of conflict-handling modes teachers used in the kinds of conflicts they faced. Their scores were arranged in descending order by percentile, with the respondent's highest score indicating his/her most frequently used conflict mode, differentiated as: collaborating, competing, accommodating, avoiding and compromising.

\section{Data Collection and Analysis}


As mentioned previously, the data were collected via two questionnaires submitted to EFL teachers in print, to take home and bring over within a week. The two questionnaires were printed on two sides of one sheet along with a brief instructions section above each page. The researcher also explained the purpose of research and what respondents were required to do upon handing in the questionnaires. The content was in English.

The collected data entered SPSS21 for the required descriptive and inferential statistical analyses. Frequency, percentile, Chi-squared test, Pearson chi-square and Fisher's exact test were run to analyze the data. The relevant findings are reported in Tables and Figures.

\section{RESULTS}

\section{A. Answer to the First Research Question}

RQ1: What proportion of Iranian EFL teachers in the private sector are task-oriented and what proportion are relation-oriented in leadership style?

The frequency and percentage of task-oriented and relation-oriented leadership styles were estimated and reported in Table 2.

TABLE 2

RESEARCH PARTICIPANTS' LEADERSHIP STYLE

\begin{tabular}{ccc} 
& RESEARCH PARTICIPANTS LEADERSHIP STYLE & Percent \\
\hline Leadership style & Frequency & 51.0 \\
\hline task-oriented & 26 & 49.0 \\
\hline relation-oriented & 25 & 100.0 \\
\hline Total & 51 &
\end{tabular}

As it can be observed, $51 \%$ of the participants were task-oriented and $49 \%$ showed to be relation-oriented in their leadership style. This information can be better compared in Figure 4.1.

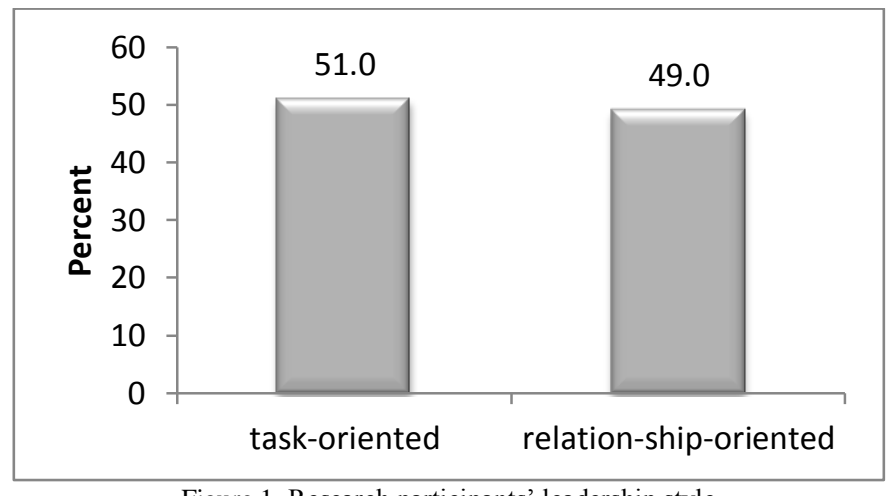

Figure 1. Research participants' leadership style

Chi-squared test was run to see whether there was a statistically significant difference between the participants in terms of the leadership style they used. The results are summarized in Table 3.

TABLE 3

\begin{tabular}{cc} 
CHI-SQUARED TEST RESULTS OF TEACHERS' & LEADERSHIP STYLES \\
\hline & Leadership style \\
\hline Chi-square & 0.020 \\
\hline df & 1 \\
\hline Asymp. Sig. & 0.889 \\
\hline
\end{tabular}

As it can be observed, no statistically significant divergence was found between the two leadership styles used in the target group. As evident, the significance level was estimated at .889, which exceeds .05. Thus, at a confidence interval of $95 \%$, it can be concluded that there is no statistically significant difference between the use of the two leadership styles (task-oriented vs. relation-oriented) among Iranian EFL teachers.

\section{B. Answer to the Second Research Question}

RQ2: Which conflict management styles are more prevalent among task-oriented and which are more prevalent among relation-oriented Iranian EFL teachers?

Firstly, the distribution of conflict management styles among all EFL teachers participating in this research was estimated and summarized in Table 4. 
TABLE 4

Distribution of TEACHERS' CONFLict MANAGEMENT STYLES AMONG ALl TEACHERS

\begin{tabular}{ccc}
\hline Conflict management & Frequency & Percent \\
\hline Collaborating & 13 & 25.5 \\
\hline Competing & 3 & 5.9 \\
\hline Avoiding & 4 & 7.8 \\
\hline Accommodating & 20 & 39.2 \\
\hline Compromising & 11 & 21.6 \\
\hline Total & 51 & 100.0 \\
\hline
\end{tabular}

As it can be observed in Table 4, the most frequent conflict management style is accommodating (39.2\%) and the least frequent is competing (5.9\%). This information is schematically presented in Figure 2.

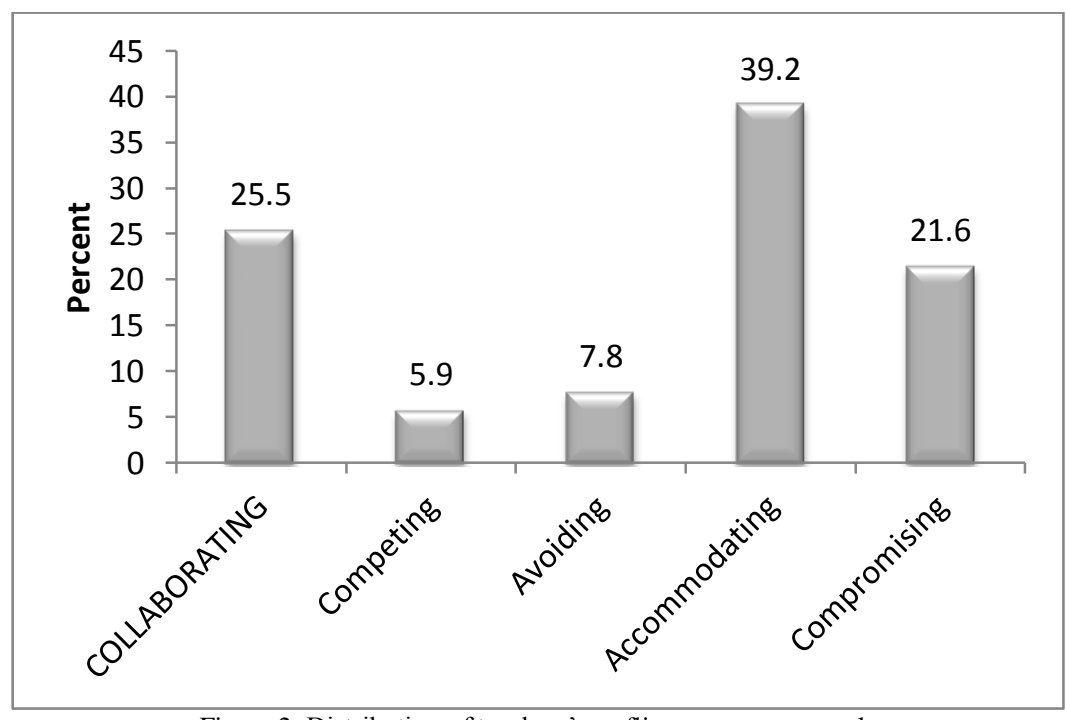

Figure 2. Distribution of teachers' conflict management style

Then, the distribution of conflict management styles among task-oriented EFL teachers was explored and the relevant findings are reported here.

TABLE 5

DisTRIBUTION OF CONFLICT MANAGEMENT STYLES AMONG TASK-ORIENTED TEACHERS

\begin{tabular}{ccc}
\hline Conflict management & Frequency & Percent \\
\hline Collaborating & 3 & 11.5 \\
\hline Competing & 1 & 3.8 \\
\hline Avoiding & 3 & 11.5 \\
\hline Accommodating & 15 & 57.7 \\
\hline Compromising & 4 & 15.4 \\
\hline Total & 26 & 100.0 \\
\hline
\end{tabular}

As it can be observed, the most prevalent conflict management style among task-oriented teachers was accommodating (57.7\%). Next came the compromising style (15.4\%), collaborating and avoiding styles (11.5) and the least frequent style was competing $(3.8 \%)$. Chi-squared test was run to see whether the difference between and among these styles was statistically significant or not. The results can be seen here.

TABLE 6

CHI-SQUARED TEST RESULTS OF CONFLICT MANAGEMENT STYLES OF TASK-ORIENTED TEACHERS

\begin{tabular}{cc}
\hline & Conflict management \\
\hline Chi-square & 24.000 \\
\hline df & 4 \\
\hline Asymp. Sig. & 0.000 \\
\hline
\end{tabular}

The Chi-squared test results showed that the difference between and among the five conflict management styles adopted by task-oriented teachers was statistically significant $(\mathrm{p}=.000, \mathrm{CI}=95 \%)$. It can be concluded that task-oriented teachers mostly adopted the accommodating conflict management style.

In a similar way, the distribution of conflict management styles was explored among relation-oriented EFL teachers and the results were presented below. 
TABLE 7

DISTRIBUTION OF CONFLICT MANAGEMENT STYLES AMONG RELATION-ORIENTED TEACHERS

\begin{tabular}{ccc}
\hline Conflict management & Frequency & Percent \\
\hline Collaborating & 10 & 40.0 \\
\hline Competing & 2 & 8.0 \\
\hline Avoiding & 1 & 4.0 \\
\hline Accommodating & 5 & 20.0 \\
\hline Compromising & 7 & 28.0 \\
\hline Total & 25 & 100.0 \\
\hline
\end{tabular}

As it can be observed, the majority of relation-oriented teachers used collaborating conflict management style (40\%). Next came the compromising style (28\%) and accommodating (20\%). The least frequent conflict management styles among relation-oriented teachers were competing and avoiding $(8 \%, 4 \%)$. Chi-squared test was run to check the difference among these styles. The relevant findings are summarized in Table 8.

TABLE 8

CHI-SQUARED TEST RESUlTS OF CONFLICT MANAGEMENT STYLES OF RELATION-ORIENTED TEACHERS Conflict management

\begin{tabular}{lc}
\hline Chi-square & 10.800 \\
\hline df & 4 \\
\hline Asymp. Sig. & 0.029 \\
\hline
\end{tabular}

As indicated, the p-value was estimated at .02, which is lower than .05. This shows that the difference among conflict management styles of relation-oriented teachers (in terms of leadership) is statistically significant (at a confidence interval of 95\%). The majority of relation-oriented teachers adopted the collaborating conflict management style (40\%). Task-oriented and relation-oriented teachers can be better compared and contrasted in terms of conflict management style in the following Figure.

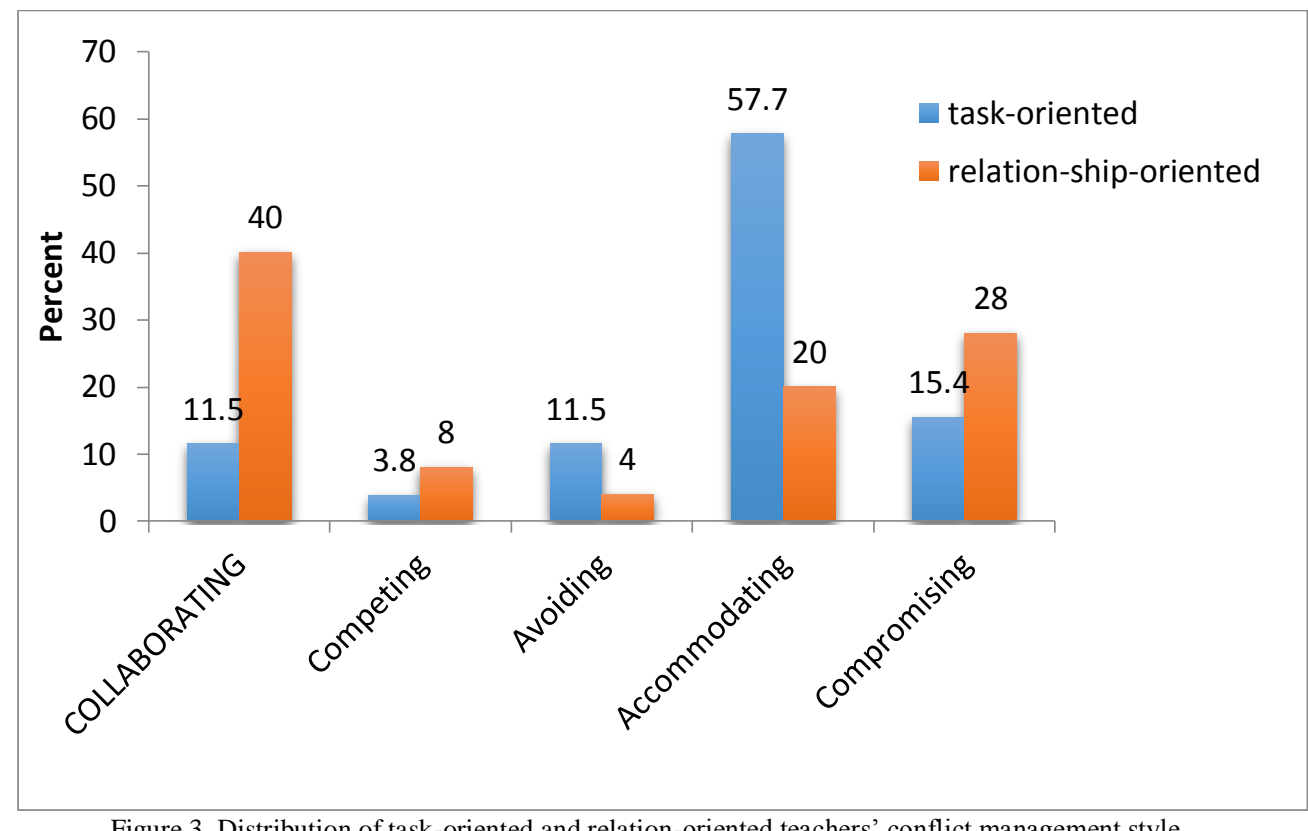

Figure 3. Distribution of task-oriented and relation-oriented teachers' conflict management style

\section{Answer to the Third Research Question}

RQ3: Is there any statistically significant difference between demographic categories of Iranian EFL teachers in terms of leadership style and conflict management styles?

This question was further broken into three secondary questions beginning with:

RQ3.1. Is there any statistically significantly difference between male and female EFL teachers in terms of leadership and conflict management styles?

The difference between male and female EFL teachers' use of leadership style is presented in Table 9. 
TABLE 9

DiSTRIBUTION OF LEADERSHIP STYLE AMONG MALE AND FEMALE TEACHERS

\begin{tabular}{|c|c|c|c|c|c|}
\hline & & & \multicolumn{2}{|c|}{ Leadership style } & \multirow[t]{2}{*}{ Total } \\
\hline & & & task-oriented & relation-oriented & \\
\hline \multirow{4}{*}{ Gender } & \multirow{2}{*}{ female } & Count & 18 & 19 & 37 \\
\hline & & $\%$ within gender & $48.6 \%$ & $51.4 \%$ & $100.0 \%$ \\
\hline & \multirow[t]{2}{*}{ male } & Count & 8 & 6 & 14 \\
\hline & & $\%$ within gender & $57.1 \%$ & $42.9 \%$ & $100.0 \%$ \\
\hline
\end{tabular}

As it can be observed in Table 9, 51.4\% of female teachers were relation-oriented while $48.6 \%$ were task-oriented in terms of leadership style. Among the male participants, $57.1 \%$ were task-oriented while $42.9 \%$ were relation-oriented. Chi-squared test was run to see whether the difference between male and female participants in terms of leadership style was statistically significant or not. Here are the results:

TABLE 10

CHI-SQUARED TEST RESUltS OF LEADERShIP STYLES OF MALE AND FEMALE TEACHERS

\begin{tabular}{lc}
\hline & gender $*$ Leadership style \\
\hline Pearson Chi-Square & 0.293 \\
\hline df & 1 \\
\hline Asymp. Sig. & 0.588 \\
\hline
\end{tabular}

As it is evident, the p-value was estimated at .5 , which exceeds .05 and shows that the difference between the two groups (male vs. female) was not statistically significant. In other words, at a confidence interval of $95 \%$, we can say that male and female teachers did not differ significantly in terms of leadership style. Thus, the relevant research hypothesis cannot be rejected.

A similar comparison was made in terms of the conflict management style. The results are presented in Table 11.

TABLE 11

Distribution of CONFLiCt MANAgEMENT STYLES AMONG MALE AND FEMALE TEACHERS

\begin{tabular}{|c|c|c|c|c|c|c|c|c|}
\hline & \multirow{2}{*}{\multicolumn{5}{|c|}{ Conflict management style }} & \multirow{3}{*}{ Total } \\
\hline & & & & & & & & \\
\hline & & & Collaborating & Competing & Avoiding & Accommodating & Compromising & \\
\hline \multirow[t]{4}{*}{ gender } & \multirow[t]{2}{*}{ female } & Count & 10 & 1 & 2 & 2 & 6 & 21 \\
\hline & & $\%$ within gender & $47.6 \%$ & $4.8 \%$ & $9.5 \%$ & $9.5 \%$ & $28.6 \%$ & $100.0 \%$ \\
\hline & \multirow[t]{2}{*}{ male } & Count & 3 & 2 & 2 & 18 & 5 & 30 \\
\hline & & $\%$ within gender & $10.0 \%$ & $6.7 \%$ & $6.7 \%$ & $60.0 \%$ & $16.7 \%$ & $100.0 \%$ \\
\hline
\end{tabular}

As indicated in Table 11, the majority of female teachers (47.6\%) adopted a collaborating conflict management style in class. Next came the compromising style (28.6\%). The least frequently used conflict management style by female teachers showed to be competing (4.8\%). Among male teachers, the most prevalent conflict management style was accommodating $(60 \%)$ while the least frequent conflict management styles used in class were competing and avoiding (6.7\%). Fisher's exact test results are presented in Table 12.

TABLE 12

Fisher's EXACT TEST RESUltS OF CONFLICT MANAGEMENT STYLES OF MALE AND FEMALE TEACHERS

\begin{tabular}{lc}
\hline & gender * conflict management style \\
\hline Fisher's Exact Test & 12.341 \\
\hline Exact Sig. (2-sided) & 0.007 \\
\hline
\end{tabular}

As the results show, the estimated p-value (.007) is below .05, which shows a statistically significant difference in the use of conflict management styles between male and female participants. In other words, at a confidence interval of $95 \%$, it can be maintained that there is a statistically significant difference between male and female teachers in terms of conflict management style. Thus, the null hypothesis concerning this relation can be rejected.

The next secondary question of RQ3 compared younger and older EFL teachers in terms of their preferred leadership and conflict management styles.

RQ3.2. Is there any statistically significant difference between younger (20-30 yrs.) and older (>30 yrs.) EFL teachers in terms of leadership and conflict management styles?

First, the comparison in terms of leadership style is made and the relevant findings are presented here.

TABLE 13

\begin{tabular}{|c|c|c|c|c|c|}
\hline \multicolumn{6}{|c|}{ DISTRIBUTION OF LEADERSHIP STYLE AMONG YOUNGER AND OLDER TEACHERS } \\
\hline & & & \multicolumn{2}{|c|}{ Leadership style } & \multirow[t]{2}{*}{ Total } \\
\hline & & & task-oriented & relation-oriented & \\
\hline \multirow[t]{4}{*}{ AGE } & \multirow[t]{2}{*}{ 20-30 } & Count & 4 & 17 & 21 \\
\hline & & $\%$ within age & $19.0 \%$ & $81.0 \%$ & $100.0 \%$ \\
\hline & \multirow[t]{2}{*}{$>\mathbf{3 0}$} & Count & 22 & 8 & 30 \\
\hline & & $\%$ within age & $73.3 \%$ & $26.7 \%$ & $100.0 \%$ \\
\hline
\end{tabular}


As indicated above, $81 \%$ of teachers between 20-30 years of age adopted a relation-oriented style in leadership. $19 \%$ of these teachers adopted a task-oriented style. As for those above 30 years of age, $73.3 \%$ showed to follow taskoriented leadership style while $26.7 \%$ followed relation-oriented style. The results of the Chi-squared test are presented below.

TABLE 14

CHI-SQUARED TEST RESULTS OF LEADERSHIP STYLES OF YOUNGER AND OLDER TEACHERS
\begin{tabular}{lc}
\hline Pearson Chi-Square & AGE $*$ Leadership style \\
\hline df & 14.567 \\
\hline Asymp. Sig. & 1 \\
\hline
\end{tabular}

As it can be observed, the p-value was estimated at .000 , which is lower than .05 and it can be concluded that the difference between the two groups (age groups) in terms of the use of leadership style is statistically significant at a confidence interval of $95 \%$. Thus, the null hypothesis can be rejected.

A similar comparison was made between younger and older teachers in terms of their conflict management style. The results are presented in Table 15.

TABLE 15

Distribution OF CONFLICT MANAGEMENT STYLES AMONG YOUNGER AND OLDER TEACHERS

\begin{tabular}{|c|c|c|c|c|c|c|c|c|}
\hline & & & \multicolumn{5}{|c|}{ Conflict management style } & \multirow[t]{2}{*}{ Total } \\
\hline & & & Collaborating & Competing & Avoiding & Accommodating & Compromising & \\
\hline \multirow{4}{*}{ AGE } & \multirow{2}{*}{$20-30$} & Count & 10 & 1 & 2 & 2 & 6 & 21 \\
\hline & & $\%$ within age group & $47.6 \%$ & $4.8 \%$ & $9.5 \%$ & $9.5 \%$ & $28.6 \%$ & $100.0 \%$ \\
\hline & \multirow[t]{2}{*}{$>\mathbf{3 0}$} & Count & 3 & 2 & 2 & 18 & 5 & 30 \\
\hline & & $\%$ within age group & $10.0 \%$ & $6.7 \%$ & $6.7 \%$ & $60.0 \%$ & $16.7 \%$ & $100.0 \%$ \\
\hline
\end{tabular}

As it can be seen in the above table, $47.6 \%$ of younger teachers (20-30 years of age) adopted a collaborating conflict management style. $28.6 \%$ of the same age group adopted a compromising style. $9.5 \%$ of this group either adopted an avoiding or accommodating conflict management style. The least frequently used conflict management style in this group was competing $(4.8 \%)$. In the other age group (>30 years of age), the most frequently used conflict management style was accommodating (60\%). Next came the compromising style (16.7\%). 10\% of teachers in this age group followed a collaborating style in managing conflicts in class. The least frequently used conflict management styles in this group were competing and avoiding (6.7\%). Chi-squared test was run and the results are presented here.

TABLE 16

CHI-SQuARED TEST RESUlts OF CONFLICT MANAGEMENT STYLES OF YOUNGER AND OLDER TEACHERS AGE * Conflict management style

\begin{tabular}{lc}
\hline Fisher's Exact Test & 16.693 \\
\hline Exact Sig. (2-sided) & 0.001 \\
\hline
\end{tabular}

As the estimated p-value is .001 (lower than .05), so it is statistically significant. In other words, it can be concluded that at a confidence interval of $95 \%$, the difference between the two age groups in terms of using conflict management style is statistically significant. Thus, the null hypothesis can be rejected.

The next secondary question of RQ3 compared experienced and novice EFL teachers in terms of their preferred leadership and conflict management styles.

RQ3.3. Is there any statistically significant difference between experienced EFL teachers ( $>5$ yrs.) and novices $(<5$ yrs.) in terms of leadership and conflict management styles?

The prevalence of leadership styles was firstly explored among experienced and novice EFL teachers and the comparative results are summarized in Table 17.

TABLE 17

DISTRIBUTION OF LEADERSHIP STYLE AMONG EXPERIENCED AND NOVICE TEACHERS

\begin{tabular}{|c|c|c|c|c|c|}
\hline & & & \multicolumn{2}{|c|}{ Leadership style } & \multirow[t]{2}{*}{ Total } \\
\hline & & & task-oriented & relation-oriented & \\
\hline \multirow[t]{4}{*}{ Years of Experience } & \multirow[t]{2}{*}{$<5$} & Count & 8 & 16 & 24 \\
\hline & & $\%$ within experience & $33.3 \%$ & $66.7 \%$ & $100.0 \%$ \\
\hline & \multirow[t]{2}{*}{$>5$} & Count & 18 & 9 & 27 \\
\hline & & $\%$ within experience & $66.7 \%$ & $33.3 \%$ & $100.0 \%$ \\
\hline
\end{tabular}

As it can be seen, among experienced teachers, $66.7 \%$ adopted a task-oriented style while $33.3 \%$ followed a relationoriented leadership style. Among novice teachers, $66.7 \%$ were relation-oriented while $33.3 \%$ were task-oriented. The results of the Chi-squared test are presented below. 
TABLE 18

CHI-SQUARED TEST RESULTS OF LEADERSHIP STYLES OF EXPERIENCED AND LESS EXPERIENCED TEACHERS

\begin{tabular}{lc}
\hline & AGE $*$ Leadership style \\
\hline Pearson Chi-Square & 5.649 \\
\hline df & 1 \\
\hline Asymp. Sig. & 0.017
\end{tabular}

As it can be inferred from the above-mentioned information, the p-value was estimated at .01, which is lower than .05. This would point to the fact that the difference between the two groups (work experience) is statistically significant in terms of the leadership style they used. Thus, the relevant null hypothesis can be rejected.

A similar comparison was made in terms of conflict management style, and the results can be seen in Table 19.

TABLE 19

Distribution OF CONFliCt MANAGEMENT STYLES AMONG EXPERIENCED AND NOVICE TEACHERS

\begin{tabular}{|c|c|c|c|c|c|c|c|c|}
\hline & & & \multicolumn{5}{|c|}{ Conflict management style } & \multirow[t]{2}{*}{ Total } \\
\hline & & & Collaborating & Competing & Avoiding & Accommodating & Compromising & \\
\hline \multirow{4}{*}{ Years } & \multirow[t]{2}{*}{$<5$} & Count & 8 & 2 & 1 & 8 & 5 & 24 \\
\hline & & $\%$ within experience & $33.3 \%$ & $8.3 \%$ & $4.2 \%$ & $33.3 \%$ & $20.8 \%$ & $100.0 \%$ \\
\hline & \multirow[t]{2}{*}{$>5$} & Count & 5 & 1 & 3 & 12 & 6 & 27 \\
\hline & & $\%$ within experience & $18.5 \%$ & $3.7 \%$ & $11.1 \%$ & $44.4 \%$ & $22.2 \%$ & $100.0 \%$ \\
\hline
\end{tabular}

As it can be observed, among experienced teachers ( $>5$ years of work), the most frequently used conflict management style was accommodating (44.4\%). Next came the compromising style $(22.2 \%)$ and collaborating style $(18.5 \%)$. After that came the avoiding style $(11.1 \%)$. The least frequent conflict management style was competing $(3.7 \%)$.

Among less experienced teachers ( $<5$ years of work), the most prevalent conflict management styles were collaborating and accommodating (33.3\%). The next frequently used conflict management style was compromising (20.8\%). The least frequent styles were competing (8.3\%) and avoiding (4.2\%).

To check whether the difference between the two groups of teachers was statistically significant (in terms of the conflict management style they used) or not, chi-squared test was run and the results are summarized below.

TABLE 20

CHI-SQUARED TEST RESUlts OF CONFLICT MANAGEMENT STYLES OF EXPERIENCED AND NOVICE TEACHERS

\begin{tabular}{cc}
\hline & $\begin{array}{c}\text { Years of Work * Conflict } \\
\text { management style }\end{array}$ \\
\hline Fisher's Exact Test & 2.782 \\
\hline Exact Sig. (2-sided) & 0.642 \\
\hline
\end{tabular}

As the estimated p-value (.6) is higher than .05 , at the confidence interval of $95 \%$, it can be concluded that the difference between the two groups is not statistically significant. Thus, the null hypothesis cannot be rejected.

\section{Discussions AND CONCLUSIONS}

\section{A. Discussion of the Results}

Initially, as the results revealed, task-oriented and relation-oriented leadership styles showed to be almost equally used by teacher participants. As previously described in the Introduction, task-oriented teachers do well when they are presented with well-defined tasks. Otherwise, they find it hard to compensate for that harmony and discipline through establishing effective interpersonal relationships with students. Yet, relation-oriented subjects, and here more specifically teachers, can do well even in the absence of well-defined tasks and can lead the class and instructions effectively by establishing effective relationships with students (Fiedler, 1958). Still, neither leadership style (which itself is subsumed under class management) can be said to be always better than the other. Nevertheless, it was worth exploring what conflict management style each group of teachers preferably and prevalently used. As the results showed, task-oriented teachers tended to use more accommodation in conflict management while relation-oriented teachers made more use of collaboration in settling down problems. Here, it can be useful to once again see the difference between accommodating and collaborating conflict management styles. As previously described in the Introduction, the former entailed yielding to others' points of view and accepting a situation even when it is not you desired. The latter entailed digging into an issue to identify the underlying concerns and trying to find a win-win solution (Thomas \& Kilmann, 1974). This finding of the present research can be explained in the light of the essential features of the two variables explored. In other words, it is quite expected that task-oriented teachers, who are by definition less adept at cooperation and negotiation skills, go for more accommodating than collaborating style in settling conflicts than relation-oriented peers. The fact that they cut down on the arguments and tend more to yield to others' points of view helps them get back to the task itself sooner and continue the class procedures through task management rather than interpersonal discussions and attempts of coming up with a win-win negotiated solution. Instead, relation-oriented teachers, as expected, showed a preference for collaborating conflict management style. In 
other words, whenever a conflict arises in class, they tend more to solve it in collaboration with others (in this case mostly the students in class) rather than succumbing to students' wants.

Teacher leadership styles were also explored across teachers' gender, age and work experience. A similar work of research was carried out by Aliakbari and Sadeghi (2014) in Iranian schools. However, teachers' age, gender and years of teaching experience were not found as meaningful factors in this research. The reason was that the effect of these variables on leadership style was explored based on participants' perceptions and reflections only, and these variables were evaluated only subjectively. In the present research, however, teachers' leadership style and conflict management style were each explored, compared and contrasted objectively across age, gender and work experience groups and statistically significant differences emerged.

Male EFL teaches showed to be more task-oriented than female teachers (who showed a preference for relationorientation). In other words, men preferred to lead the class through task management while women were better at leading interpersonal relationships in class. No similar work of research existed in the literature to compare the results with. Yet, according to some latest research on women's psychology, females find social interactions more rewarding than males in general (Borland, Aiani, Norvelle, Grantham, O’Laughlin, Terranova, Frantz \& Albers, 2019). These researchers bring physiological evidence for the claim and show how women become better social interactants, overall. As for conflict management style, male teachers showed to go more for accommodating style while female peers were more oriented toward the collaborating style. This is well expected, as task-orientation in leadership is associated with less interpersonal compromise than relation-orientation in leadership, which is better linked with collaborative style (which entails coming to shared and negotiated solutions).

As for years of work experience, the present research found that experienced teachers were more task-oriented while less experienced teachers were more relation-oriented. In addition, for conflict management, the former used more accommodating style while the latter went more for the collaborating style. In a similar attempt, Mujis, Chapman and Armstrong (2013) explored whether novice teachers could be teacher leaders or not. They conducted surveys and interviewed with novice teachers, heads, middle managers and more experienced teachers. Their results showed that novice teachers were eager and capable for exercising leadership; however, school support, senior management commitment to distributed leadership, and practical hands-on support was needed at the departmental level. Furthermore, it was argued that a stable context with consistent and coherent policies make the situation easier for teacher leadership engagement. It is certain that managing tasks is demanding for inexperienced teachers or those at the early years of teaching. As pinpointed by Mujis, Chapman and Armstrong (2013), novice teachers can gradually strike a balance in relation- and task-oriented style through time and with the help of the school/institute of affiliation.

Concerning age, in the present research, younger EFL teachers (20-30 years of age) showed to be more relationoriented than older peers (more than 30 years of age). Younger teachers also tended to rely more on collaboration to solve conflicts while older peers relied more on accommodation to tackle conflicts. Though, no similar research was there in the related literature to compare the results with, this finding can be at least partly explained in relation to higher spirits and tender energy often associated with youngsters which is not only confined to the personal world but is also brought with youngsters to their occupational world too. They are likely to spend more time establishing amiable relationships in class with students and solve problems more negotiably and patiently than older teachers.

Mind that neither the leadership styles nor conflict management styles are static in nature. What makes them worth exploring is the inherent dynamicity and potential growth. According to Afzal (2004), managers need to be trained to encourage their subordinates to use more integrating and less avoiding styles of handling conflict to improve job performance. The same can be true for teacher trainees. Teachers are managers of their class and thus require to develop appropriate class management and leadership skills. It is undeniable that much of this grows through years of experience. Yet, teacher training courses can cut the way short and raise teacher trainees' awareness of these significant concerns.

\section{B. Conclusions}

As pinpointed by Muijs and Harris (2006), teacher leadership, teacher empowerment and school improvement are closely interrelated. If teacher leaders are developed, especially in the light of the situationally-sensitive contingency theory, they can be empowered on multiple aspects: task management, interpersonal relations, class management and other relevant domains. Unfortunately, at its current state, teacher training courses in Iran significantly lack any endeavor to develop leadership and management styles. EFL teachers are hardly familiar with how they can effectively use tasks or, alternatively, interpersonal relations to lead class procedures. Similarly, they might be unaware of different conflict management styles ranging from assertiveness to cooperation. Knowledge of different conflict management styles (avoidance, accommodation, competition, collaboration and compromise) can revolutionize teacher's approach to class management, which is integral to teacher's pedagogical content knowledge (Akbari, Kiany, Ghaffarsamar \& Yazdanmehr, 2016). This knowledge diverges from teacher's disciplinary knowledge and content knowledge, which can be sometimes self-studied by teachers too. Pedagogical content knowledge is primarily gained through experience or learned from others' experience. This experience can be shared among teachers in regular meetings of community members (colleagues) or can be incorporated in teacher training courses, which are currently mainly filled with how to teach grammar, vocabulary and four language skills. However, in real classes, teachers, following whichever method, deal with different challenging situations that need to be handled efficiently and this has nothing to do with their 
language proficiency, teaching methodology and knowledge of the course. It actually taps on the artistic and practical aspects of teaching, which is context-specific. This final point lies at the heart of the contingency theory, which raises awareness of the context-specificity of managing one's working environment. Thus, many factors come to play a role, statistically significant or not, in the efficiency of managing work environment (in this case, the teaching environment).

In this research, part of the findings revealed differences between leadership and conflict management styles across gender, age and work experience. Awareness of these differences can enrich teacher training courses or professional development programs in Iran. For instance, male EFL teachers who naturally tend to use more task-oriented leadership style can be made aware of the benefits of relation-orientation in leading class too, especially at higher levels of language proficiency classes, where the boundaries between and among tasks usually blur and students tend to speak more freely in class and run free or controlled discussions. Task-orientation can be assumed to work more efficiently at lower levels of proficiency, often marked by more clear-cut and well-defined tasks in class.

The same consciousness-raising attempts can be made for conflict management. Teacher training courses can be tinted with the range of conflict management styles teachers can be equipped with in class when a conflict arises. Teachers can be encouraged to gradually move away from avoidance towards collaboration. Differences across gender, age and work experience can be incorporated at least as hints to enlighten pre-service or in-service teacher development courses. Teachers should be made aware of class management in general and conflict management in particular. In an EFL class, this becomes more salient as many language-related and non-language-related problems may occur which need to be tackled effectively. In teacher-training courses, some of the more predictable conflicts can be proposed and teachers can be shown how best to manage them. This can make the training course more practical, realistic and interesting to trainees.

\section{REFERENCES}

[1] Afzal, R. (2004). Conflict management strategies as moderators or mediators of the relationship between intragroup conflict and job performance, presented at the Annual conference of the International Association for Conflict Management, Pittsburgh, PA, June 15-18.

[2] Aliakbari, M., \& Sadeghi, A. (2014). Iranian teachers' perceptions of teacher leadership practices in schools. Educational Management Administration \& Leadership, 42(4), 576-592.

[3] Azar, F. E. \& Asiabar, A. S. (2015). Does leadership effectiveness correlates with leadership styles in healthcare executives of Iran University of Medical Sciences. Medical Journal of the Islamic Republic of Iran, 29(1): 49-53.

[4] Bohannan, P. (1967). Introduction to law \& warfare: Studies in the anthropology of conflict. Austin: University of Texas Press.

[5] Borland, J. M., Aiani, L. M., Norvelle, A., Grantham, K. N., O’Laughlin, K., Terranova, J. I., Frantz, K. J. \& Albers, H. E. (2019). Sex-dependent regulation of social reward by oxytocin receptors in the ventral tegmental area. Neuropsychopharmacology 6(3). 134-145.

[6] Emira, M. (2010). Leading to decide or deciding to lead? Understanding the relationship between teacher leadership and decision making. Educational Management Administration \& Leadership, 38(5), 591-612.

[7] Fiedler, F. E. (1958). Leader attitudes and group effectiveness. Illinois: University of Illinois Press.

[8] Gluckman, M. (1956). Customs and conflict in Africa. Oxford: Basil Blackwell publisher Limited.

[9] Gulliver, P. H. (1963). Social control in African society: A study of the Arusha: Agricultural masai of Northern Tanganyika. London: Rutledge and Kegan Paul.

[10] Huang, A. F. M., Yang, S. J.H. \& Hwang, G. H. (2010). Situational language teaching in ubiquitous learning environments. Knowledge Management and E-learning, 2(3). 312-320.

[11] Khany, R., \& Amoli, F. A. (2013). The impact of leadership style, thinking style and job satisfaction on Iranian EFL teacher retention. European Online Journal of Natural and Social Sciences: Proceedings, 2(2), 533-544.

[12] Koosha, M., Liaghat, F., \& Sadeghdaghighi, A. (2015). Analysis of Iranian EFL teachers' leadership in English language institutes. Theory and Practice in Language Studies, 5(1), 201-207.

[13] Muijs, D., Chapman, C., \& Armstrong, P. (2013). Can early careers teachers be teacher leaders? A study of second-year trainees in the teach-first alternative certification programme. Educational Management Administration \& Leadership, 41(6), $767-781$.

[14] Muijs, D., \& Harris, A. (2006). Teacher led school improvement: Teacher leadership in the UK. Teaching and teacher education, 22(8), 961-972.

[15] Northouse, P.G. (2007). Contingency theory. Leadership: theory and practice ( $4^{\text {th }}$ ed.). Thousand Oaks: CA: Sage.

[16] Nanda, S. (1994). Cultural anthropology. California: Wades worth Publishing Company.

[17] Schellenberg, J. A. (1996). Conflict resolution: Theory, research and practice. New York: State University of New York Press.

[18] Yazdanmehr, E., Akbari, R., Kiany, G., Ghaffarsamar, R. (2016). Proposing a conceptual model for teacher expertise in ELT. Theory and Practice in Language Studies, 6(3). 631-641.

Elham Yazdanmehr holds a Ph.D. of TEFL from Tarbiat Modares University of Iran. She is an assistant professor at Attar Institute of Higher Education. She does research on teacher education and material development.

Yousef Ramezani holds a Ph.D. of Human Resource Management. He is an assistant professor at Attar Institute of Higher Education in Mashhad. He does research on management studies. 
Fatemeh Aghdassi holds an M.A. of TEFL from Imam Reza University of Mashhad. She sows interest in interdisciplinary research mainly focused on Applied Linguistics. 